\title{
The Effect of Speaking Anxiety on Students Performance in Speech Class
}

\author{
Allen Christy ${ }^{1, *}$ Jufri $^{1}$, Mukhaiyar ${ }^{1}$ \\ ${ }^{1}$ Student of English Education of Graduate Program, Universitas Negeri Padang, Sumatera Barat 25131, Indonesia \\ *Corresponding author. Email: allenchristy086@gmail.com
}

\begin{abstract}
This research was designed to measure the level of anxiety faced by the students and its effect on students' performance, and the factors causing the anxiety. This study is a descriptive research. The sample of this study was the students of English Department who took speech subject at STKIP PGRI Sumatera Barat academic year 2018/2019. The participants of the research were $12(25 \%)$ out of 50 students. The researcher used three instruments in collecting the data; speaking test, questionnaire, and interview. The speaking test was a speech test and the students' performance was scored by using a scoring rubric. The questionnaire was adapted from Horwitz et al. (1986) and the scores from the Likert scale were then tabulated to identify students' level of anxiety. Last, interview was administered to find out the internal and external factors causing the anxiety. The result shows that the students, as a whole, have medium level of anxiety in the apprehension of communication, low in the evaluation of negative fear, and also low in the test of anxiety. The researcher found out that the students with low level of anxiety in those three types of anxiety performed well in the speech test. Thus, it implies that anxiety affects students' performance. From the interview, it can be concluded that the students' anxiety derived mostly from the internal factors; fear of being laughed at or their unconfidence.
\end{abstract}

Keywords: performance, speaking anxiety, speech

\section{INTRODUCTION}

Speaking can be interpreted as produce words that have a meaning as a means of communication. This kind of communication is important for people to complete their needs to transfer ideas, message, opinion and information. For some people, mastering the art of speaking is important thing in learning a foreign language. Mostly, people measure the ability of foreign language students by their speaking ability. Speaking is the ability to perform the linguistic knowledge in actual communication. Related to this [6] when people learn English, they must have competence to use it for communication, especially speaking because one of important function of spoken language is transactional to deliver information to social community. In addition [4] describes that speaking foreign language is not easy since oral communication need the ability to use the language appropriately in a social interaction. Furthermore, [15] define speaking as an interactive process of constructing meaning during the interaction. In order to make speaking runs well in learning, there are four things should considered, they are context, participant, speaker's experience and knowledge also the purpose of speaking. Realizing the importance of English for communication, Indonesian government has made English compulsory to learn for all students in country at any levels of education. In other words, today English has become one of compulsory subjects that should be completed by students from elementary schools up to universities. In learning English in Universities, especially English major, there are four skills to generate such as listening, speaking, reading, and writing. Today, speaking may be a difficult task for several students as a result of it desires interactions. the opposite four abilitys can be practiced alone, except for speaking, the scholars cannot extremely speak alone, that's why students ought to create each effort potential to seek out someone to talk with. Student should have sensible command of communication skill of English therefore on prepare their future careers and lives. In reality, although English has been tutored for a minimum of six years at school level in Indonesia, that is in lyceum college and senior high school college level and conjointly in many elementary colleges as native 
content subject, the scholars still have some difficulties in learning English whether it is the productive or receptive skill, especially speaking. The incontrovertible fact that several faculty graduates cannot communicate in English has become national downside in Indonesia [1]. Many students got the medium score of Speaking subject, this was found by researcher based on her preliminary research at STKIP PGRI Sumatera Barat. The researcher also found some factors that cause students got low score in Speaking, for example: the students prefer to be silent in the class when the lectured asked them, the students also keep silent when the lecture asked them the question even they know the answer. The students also difficult to overcome their emotion like twitchy, confidence lackness, sheepish, the students worry to make mistake when they stand up in front of the class. Based on some problems above, anxiety becomes the bigger factor.

Some experts define the speaking anxiety as a common fear [3]. The common reason for speaking anxiety are as follows: fear of abasement, to prepare badly, lack of confidence related to the physical appearance, the fear of being criticized by the audience when there is no perfect performance, anxiety of low self-esteem, indifference of the audience, the speaker to be inexperienced, the fear of making a mistake, the fear of failure[7]. [5] proposed three levels of anxiety; trait anxiety individuals like hood of becoming anxious in any situation, state anxiety (the anxiety experienced in relation to some particular event or act), and situational specific anxiety (anxiety experienced in specfic type of situation). From these three levels of anxiety, trait anxiety has not proved to be useful in predicting language achievement so that the previous researches only focused on state anxiety and situational specific anxiety [13]. In lines [8] anxiety can be divided into three types, namely: trait anxiety, state anxiety and situation-specific anxiety.

On the other hand, [7] categorized foreign language anxiety into three. Then, the researcher used this for indicators her questionnaire, they are (1)the apprehension of communication, (2)the evaluation of negative fear, and (3) the test of anxiety.

\section{METHOD}

The design of this research was descriptive research. [9] [2] states that "a descriptive study determines and describes the way things are". In this research, the researcher involved in collecting the data about speaking anxiety and its effect on students performance in Speech Class at STKIP PGRI Sumatera
Barat. The population of this research was the second year students at STKIP PGRI Sumatera Barat in academic year 2018/2019. There were two classes of Speech class, total population was 50 students, but [10] suggest for descriptive research, the sample of $10 \%$ is considered minimum. The researcher took 12 students as the sample of the research $(25 \%$ of the population $=$ 12 students). The sample selected randomly.

The instrument of this research was questionnaire. The questionnaire items made by the indicator of students anxiety as proposed by [13].Then, the items in the questionnaire adapted from [11] under the term Foreign Language Classroom Anxiety Scale (FLCAS). The purpose of the questionnaire was to know the level of students speaking anxiety. The level of anxiety categorized into three; low, medium and high.
SD : Strongly Disagree
D : Disagree
N : Neither agree nor Disagree
A : Agree
SA : Strongly Agree

Table 1. Foreign Language Classroom Anxiety Scale (FLCAS).

\begin{tabular}{|c|c|c|c|c|c|c|}
\hline \multirow[t]{2}{*}{ No } & \multirow[t]{2}{*}{ Question } & \multicolumn{5}{|c|}{ Answer } \\
\hline & & SD & $\mathrm{D}$ & $\mathrm{N}$ & A & SA \\
\hline 1 & $\begin{array}{l}\text { I never feel quite } \\
\text { sure of myself when } \\
\text { I am speaking } \\
\text { English. }\end{array}$ & & & & & \\
\hline 2 & $\begin{array}{l}\text { I tremble when I } \\
\text { know that I am going } \\
\text { to be called on in } \\
\text { Speech class. }\end{array}$ & & & & & \\
\hline 3 & $\begin{array}{l}\text { I really enjoy follow } \\
\text { the Speech test. }\end{array}$ & & & & & \\
\hline 4 & $\begin{array}{l}\text { I start to panic when } \\
\text { I have to speak } \\
\text { without preparation } \\
\text { in Speech class }\end{array}$ & & & & & \\
\hline 5 & $\begin{array}{l}\text { I worry about } \\
\text { consequences of } \\
\text { failing my Speech } \\
\text { class. }\end{array}$ & & & & & \\
\hline 6 & $\begin{array}{l}\text { In Speech class I feel } \\
\text { really worry so, I } \\
\text { forgot all the things } \\
\text { about the material. }\end{array}$ & & & & & \\
\hline 7 & $\begin{array}{l}\text { I feel ashamed when } \\
\text { I have to answer the } \\
\text { question voluntarily } \\
\text { at Speech class. }\end{array}$ & & & & & \\
\hline 8 & $\begin{array}{l}\text { I am not worry } \\
\text { making mistake in } \\
\text { Speech class }\end{array}$ & & & & & \\
\hline 9 & It frightens me when & & & & & \\
\hline
\end{tabular}




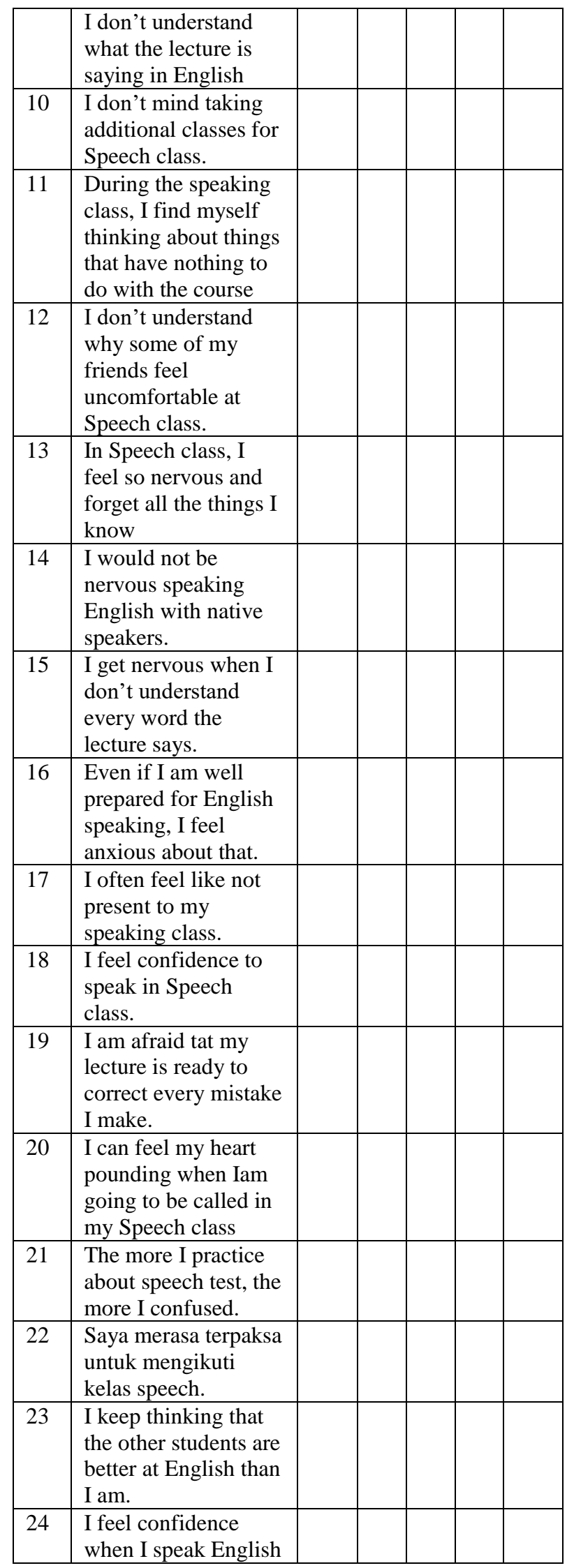

\begin{tabular}{|l|l|l|l|l|l|l|}
\hline & $\begin{array}{l}\text { in front of my } \\
\text { classmates. }\end{array}$ & & & & & \\
\hline 25 & $\begin{array}{l}\text { Speech clss moves so } \\
\text { quickly I worry about } \\
\text { getting left behind. }\end{array}$ & & & & & \\
\hline 26 & $\begin{array}{l}\text { I feel more tense and } \\
\text { nervous in Speech } \\
\text { class than the other } \\
\text { subject. }\end{array}$ & & & & & \\
\hline 27 & $\begin{array}{l}\text { I get nervous and } \\
\text { confused when I } \\
\text { speak in front of the } \\
\text { class. }\end{array}$ & & & & & \\
\hline 28 & $\begin{array}{l}\text { I feel very sure and } \\
\text { relax at speech class. }\end{array}$ & & & & & \\
\hline 29 & $\begin{array}{l}\text { I am afraid the other } \\
\text { students will laugh at } \\
\text { me when I perform } \\
\text { in front of the class. }\end{array}$ & & & & & \\
\hline 30 & $\begin{array}{l}\text { I get nervous when } \\
\text { the lecture ask me } \\
\text { the questions which I } \\
\text { haven't prepared } \\
\text { before. }\end{array}$ & & & & & \\
\hline
\end{tabular}

\section{RESULTS AND DISCUSSION}

The researcher analyzed the questionnaire and arranges participants' response in the table used Likert Scale. Actually, there is no a precise instruction or guideline to analyze the responses from FLCAS. Then, [12] as well as [14] suggested a simple method to analyze the questionnaire, this research used Liker scale because mostly people used this scale for analyze the questionnaire. Likert Scales have the advantage that they do not expect a simple yes / no answer from the respondent, but rather allow for degrees of opinion, and even no opinion at all. In its final form, the Likert scale is a five point scale which is used to allow the individual to express how much they agree or disagree with a particular statement.

In this research, the researcher used thirty items of the questionnaire, that the total multiple score was one hundred and fifty, then the full score minus thirty to attain the vary. Next, the scores more than a hundred and twenty were categorized as high anxiety, scored range from ninety up to one hundred and nineteen were categorized medium anxiety and scores below ninety categorized as low anxiety.

Based on the data above, the researcher can categorized the level of participants' anxiety. The data showed that 8 participants categorized as low performance high anxiety, 4 got medium performance medium anxiety and no one got high performance low anxiety. 
The result can simply be seen through the graphic below:

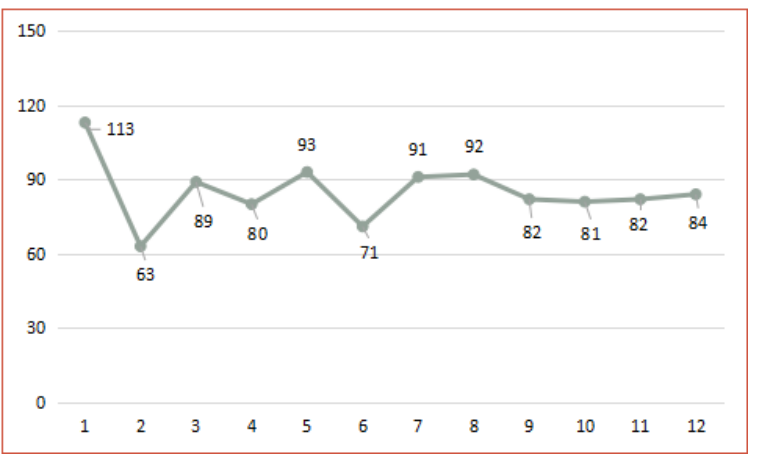

Fig. 1 The graphic of the participants' score from questionnaire and their level of anxiety

On the next analysis, the researcher tried to see how anxiety affected the students' speaking performance. Therefore, the researcher put the findings on a table so that the data can be easily interpreted. The table is as follow;

Table 2 Level of anxiety and the score at student performance

\begin{tabular}{|c|c|c|c|c|c|c|}
\hline Partici- & Total & Level & \multicolumn{2}{|c|}{ Level of Anxiety } & Perfor- \\
\cline { 4 - 7 } & CA & FNE & TA & mance \\
\hline 1 & 113 & Medium & High & $\begin{array}{c}\text { Mediu } \\
\mathrm{m}\end{array}$ & Low & C \\
\hline 2 & 63 & Low & Low & Low & Low & A \\
\hline 3 & 89 & Low & Low & $\begin{array}{c}\text { Mediu } \\
\mathrm{m}\end{array}$ & $\begin{array}{c}\text { Medi } \\
\text { um }\end{array}$ & C \\
\hline 4 & 80 & Low & Low & $\begin{array}{c}\text { Low } \\
\text { um }\end{array}$ & B \\
\hline 5 & 93 & Medium & $\begin{array}{c}\text { Medi } \\
\text { um }\end{array}$ & $\begin{array}{c}\text { Mediu } \\
\mathrm{m}\end{array}$ & Low & C \\
\hline 6 & 71 & Low & Low & Low & Low & A \\
\hline 7 & 91 & Medium & Low & $\begin{array}{c}\text { Mediu } \\
\mathrm{m}\end{array}$ & Low & B \\
\hline 8 & 92 & Medium & $\begin{array}{c}\text { Medi } \\
\text { um }\end{array}$ & $\begin{array}{c}\text { Mediu } \\
\mathrm{m}\end{array}$ & Low & C \\
\hline 9 & 82 & Low & Low & Low & Low & A \\
\hline 10 & 81 & Low & Low & Low & Low & A \\
\hline 11 & 82 & Low & Low & Low & Low & B \\
\hline 12 & 84 & Low & $\begin{array}{c}\text { Medi } \\
\text { um }\end{array}$ & Low & Low & B \\
\hline
\end{tabular}

From the table, it can be assumed that a student will possibly perform well when he/she has low anxiety on each indicator of speaking anxiety. Moreover, students with two low and one medium level of anxiety will probably perform well enough. However, having three low level of anxiety will not guarantee a student to perform very well in speaking test. Perhaps, it is because of the speaking skill, not the anxiety. In other words, a student may not hesitate to speak in a speaking class or test, but still, his/her English proficiency is one of many factors contributing the his/her speaking performance. And last, the table shows that students who got one low and two medium tended to perform moderately. However, Student 3 and 7 show an interesting finding. Being categorized low on speaking anxiety did not make Student 3 to have better performance in speaking test, and in contrary, being categorized to have medium level of anxiety did not stop Student 7 to perform well. The researcher assumes that Student 3 got $\mathrm{C}$ in speaking test due to his/her low English proficiency no matter if he/she did not feel anxious during the test. In addition, Student 7 who was assumed to be anxious in speaking test or class could perform well, perhaps, because he/she could fulfill the indicators in speaking test.

Furthermore, the table also provides us with an evidence that the apprehension of communication and the evaluation of negative fear affect the students' performance much more than test anxiety. Students who got $\mathrm{C}$ tended to have low anxiety on test anxiety, and yet, they have medium level on the apprehension of communication and the evaluation of negative fear. In other words, the students feared other students' evaluation more than they feared being evaluated in a speaking test.

In conclusion, speaking anxiety indeed affects students' performance in speaking test. However, anxiety is only one of so many factor affecting speaking performance. Reducing anxiety will then help the students to perform better in speaking class or test.

\section{CONCLUSION}

Based on the research result and discussion above, it can be concluded that anxiety effect to students' performance, students with high anxiety have low performance and students with low anxiety will have good performance in speech. From the three indicators of questionnaire, two of the indicator results' got low performance of students, it means the anxiety was high they are fear of negative evaluations and test anxiety, 
and the other indicator got medium level of anxiety, it means the anxiety was medium.

\section{ACKNOWLEDGMENT}

First and foremost, the researcher would like to say Alhamdulillah all praise to Allah SWT for giving me strength and encouragement during all the moments in completing this research. Then, the researcher gives a massive thank to Prof. Dr. Mukhaiyar, M.Pd as the Advisor. The researcher greatly appreciates all of his contributions of time and ideas, as well as his support of the researcher's interest in the current topic of the research. It was an honour to have such knowledgeable advisor who challenged and encouraged to do the best throughout the whole time spent on writing the research. The researcher would also like to show the gratitude to Dr. Muhammad Al Hafiz, S.S., M.A and Dr. Havid Ardi, S.Pd. M. Hum as a contributors in this research, they are amazing and knowledgeable constributors. Without their guidance and persistent help, it would not have been possible

\section{REFERENCES}

[1] Alwasilah A. Chaedar. (2000). Pokoknya Kualitatif Dasar-Dasar Merancang dan Melakukan Penelitian Kulaitatif. Jakarta: Pustaka Jaya Jakarta.

[2] Ariola. (2006). Principles and Methods of Research' 2006 Ed. Manila: Rex Book Store.

[3] Breakey, L, K. (2005). "Fear of Public Speaking the Role of the SLP”. Seminars in Speech and Language, 26, 107-117.'

[4] Brown, G., Yule, G. (1999). Teaching the Spoken Language. USA: Cambridge University Press.

[5] Brown, H. D. (2000). Principles of Language Learning and Teaching. New York: Addison Wesley Longman.

[6] Burns, A \& Joyce, H. (1997). Focus on Speaking. Sydney: Macquire University Press

[7] Daly, J. A. (1991). Understanding Communication Apprehension: "An Introduction for Language Educators". Englewood Cliffs, NJ: Prenitice Hall. [8] Ellis, R. (1994). The Study of Second Language Acquisition. Oxford: Oxford University Press.
[9] Gay,L.R and Peter Airaisian. 2000. Educational Research: Competencies for Analysis and Application. New Jersey: Prentice-Hall, Inc [10] Gay, L. R., Mills, G. E., \& Airasian, P. W. (2009). Educational research: competencies for analysis and applications ( $9^{\text {th }}$ ed.). Upper Saddle River, N. J.: Merrill/Pearson.

[11] Horwitz, E.K., Horwitz, M.B. \& Cope, J.A. (1986). Foreign language classroom anxiety. Modern Language Journal 70, pp. 125-132

[12] Kriangkrai, Y. \& Siriluck, U. (2012). A Measure of EFL Public Speaking Class Anxiety: Scale

Development and Preliminary Validation and Reliability. English Language Teaching. Vol. 5. No. 12. 2012. ISSN 1916-4742 E- ISSN 1916-4750. Published by Canadian Center of Science and Education.ss.

[13] MacIntyre, P. D., \& Gardner, R. C. (1991). "Methods and Result in the study of foreign language anxiety: A review of the literature". In Language Learning, 41 (1), 283-305.

[14] Öztürk, G., \& Gürbüz, N. (2013). The impact of gender on foreign language speaking anxiety and motivation. Procedia-Social and Behavioral Sciences, 70, 654-665.

[15] Shumin, K. (1997). "Factors to Consider: Developing Adult EFL Students Speaking Abilities". In English Teaching Forum, Vol. 35, No. 3, pp 8.

Retrieved from: http://eca.state.gov/forum/vols/vol35/no3/p8.htm 